\title{
KAPASITASS PENGANGGARAN DESA DI KABUPATEN MUNA PROPINSI SULAWESI TENGGARA
}

Oleh:

\author{
Jopang ${ }^{1}$, Zulfiah Larisu ${ }^{1}$, Arifin Utha ${ }^{1}$, Eko Harianto ${ }^{2}$ \\ ${ }^{1}$ Dosen Prodi Administrasi Publik Program Pascasarjana Universitas Halu Oleo \\ ${ }^{2}$ Dosen Komunikasi Pertanian Fakultas MIPA Universitas Terbuka
}

jopang@uho.ac.id

\begin{abstract}
The purpose of this study was to analyze and describe the capacity of village budgeting in Muna District. The approach used is qualitative research. The study was conducted in real-world settings, namely conducting indepth investigations into the natural context in which the processes and outputs of village budgeting take place. The study locations are 7 seaside villages and 8 non-seas villages in Muna Regency. The scope of time is three budget years, namely 2015-2017. The main data collection procedure is the study of documents. To obtain primary data, procedures for public consultation and/or focus group discussion are taken. The technical public consultation was mutually agreed upon by involving the Community Empowerment Agency and Village Government of Muna Regency as the technical agency. Public consultation material was explored and developed from the results of focus group discussions. Focus group discussions were conducted at the village level, involving Village Devices, members of the Village Consultative Body, and Village Community Empowerment Institutions. Available data are analyzed by the procedure of content analysis and qualitative descriptive analysis to reveal the stages of the village budgeting process, who is involved and what is the main role.

The results of the study show that the capacity of village budgeting in Muna Regency is not optimal, that is, the village budgeting system has not functioned properly in allocating and using inputs to produce budgetary outputs that are beneficial for achieving village development goals. Villages in Muna Regency have budget documents namely $A P B$ Desa and $R A B$ which are stipulated by village regulations.
\end{abstract}

\section{Keywords : Capacity, Budgeting. Village}




\section{PENDAHULUAN}

Kewenangan dan peran besar yang dimiliki oleh desa tentunya perlu disertai dengan kapasitas yang besar pula. Kapasitas dalam konteks sektor publik didefinisikan sebagai kemampuan individu-individu dan organisasiorganisasi publik untuk melaksanakan tugas-tugas spesifik yang dimandatkan kepadanya dan mencapai tujuan-tujuan dalam cara yang efektif dan berkelanjutan (Boyle \& O'Riordan, 2013; Roudo, Ermanita \& Arumansyah, 2013; UNDP, 2010). Dalam konteks desa, hal ini dimaknai bahwa pemerintah desa perlu memiliki kapasitas untuk melaksanakan tugas-tugas yang dimandatkan oleh peraturan perundang-undangan dan mencapai tujuan-tujuan pemerintahan desa secara efektif dan berkelanjutan.

Di antara substansi kapasitas yang penting untuk dimiliki oleh pemerintahan desa adalah kapasitas untuk mengoptimalkan penganggaran desa. Kapasitas untuk menyusun penganggaran penting karena peran dan tanggung jawab pemerintahan desa saat ini lebih luas dan strategis dibandingkan dekade yang lampau. Peran baru pemerintahan desa tersebut di atas mensyaratkan kapasitas penganggaran yang memadai. Penganggaran di sektor publik adalah proses dengan mana pemerintah atau suatu organisasi pemerintah merencanakan belanjanya, penerimaannya, pinjamannya dan aktivitas finansial lainnya di masa mendatang. Output dari proses penganggaran adalah anggaran (Allen \& Tommasi, 2001). Kapasitas penganggaran desa merefleksikan pengelolaan aspek-aspek pembelanjaan dalam cara yang lebih efisien, transparan, dan akuntabel. Untuk dapat merealisasikan penganggaran dengan baik, Pemerintah Desa dituntut untuk dapat menyusun perencanaan desa yang baik dan diikuti dengan tatakelola program yang baik pula. Perencanaan desa mencakup penyusunan Rencana Pembangunan Jangka Menengah Desa (RPJMDes) untuk jangka waktu 6 (enam) tahun; dan Rencana Kerja Pemerintah Desa (RKP DESA) yang merupakan penjabaran dari RPJM Desa untuk jangka waktu 1 (satu) tahun. Pembangunan desa yang efektif bukanlah semata-mata karena adanya kesempatan dan anggaran melainkan hasil dari penentuan pilihan-pilihan prioritas kegiatan, bukan hasil coba-coba tetapi akibat perencanaan yang baik. Selanjutnya, pemerintahan desa diharapkan mampu mengelola anggaran desa menurut azas pengelolaan keuangan desa yang baik.

Anggaran desa tidak lain adalah sumber daya publik atau uang publik yang merupakan hasil-hasil dari aktivitas sektor publik sehingga pemerintahan desa berkewajiban untuk mempersiapkan dan mengimplementasikan anggaran tersebut secara efektif. Belanja pemerintah di desa seharusnya merupakan refleksi dari kebijakan-kebijakan, prioritas-prioritas dan aktivitas pemerintahan yang memberikan efek langsung pada kesejahteraan rakyat yang lebih luas. Hal ini menunjukkan bahwa belanja desa harus terintegrasi dengan dan berpedoman kepada perencanaan desa, dengan kata lain bahwa anggaran belanja desa akan menjadi instrumen pelaksanaan perencanaan desa.

Pemilikan dokumen perencanaan desa dan penganggaran desa yang baik serta konsistensi di antara keduanya masih menjadi kendala sampai sekarang. Yulianto (2017) mengemukakan bahwa efektivitas pengelolaan anggaran desa tidak sesuai harapan. Anggaran desa tidak mampu untuk memfasilitasi program pembangunan desa, pemberdayaan masyarakat, dan penanggulangan kemiskinan. Hal ini terkait erat dengan belum tersusunnya Anggaran Pendapatan dan Belanja Desa (APBDes) menurut prinsip-prinsip tata-kelola yang baik, pelaksanaannya belum berdasarkan prinsip akuntabilitas dan transparansi, di sisi lain kerja sama tim dalam memformulasikan Rencana Kerja Pemerintah Desa (RKPDes) belum terbangun secara sinergis, kepala desa selaku pemegang kekuasaan pengelolaan keuangan desa lebih banyak berperan dan bermain dalam perencanaan, pelaksanaan, dan pelaporan pengelolaan keuangan desa.

Kenyataannya di banyak desa, perencanaan pembangunan desa belum partisipatif, peran elite desa yang mengklaim mewakili aspirasi masyarakat masih mendominasi kekuatan dalam menentukan kebijakan dan prioritas pembangunan desa. Sekarang istilah partisipasi stakeholders sebenarnya sudah populer diadopsi oleh 
pemerintah sebagai sebuah pendekatan partisipatif dalam pembangunan. Tetapi stakeholders yang terlibat dalam perencanaan pembangunan desa masih berkutat pada aktor pemerintahan desa dan lembaga-lembaga formal di tingkat desa. Keterlibatan organisasi-organisasi sektoral, organisasi kemasyarakatan yang lain, dan kelompok perempuan masih sangat terbatas. Konsekuensinya, ketika APBDesa diorientasikan untuk membiayai prioritas-prioritas yang dituangkan dalam RKPDesa maka yang dominan menikmati manfaat anggaran (APBDesa) adalah para aktor formal pemerintahan desa sendiri. Hasil pemantauan Kementerian Dalam Negeri menunjukkan bahwa kelemahan perencanaan desa dan inkonsistensi antara perencanaan dengan penganggaran desa cenderung terjadi pada desa-desa yang mempunyai kepala desa yang baru terpilih.

Kendala untuk mengoptimalkan penganggaran desa sebagaimana diuraikan di atas sangat mungkin terjadi di desa-desa di Kabupaten Muna Provinsi Sulawesi Tenggara. Pemerintahan desa di Kabupaten Muna sangat berkepentingan dengan optimalisasi penganggaran desa. Kabupaten Muna mempunyai visi "Terwujudnya Muna yang Kuat, Mandiri dan Bermartabat". Realisasi visi tersebut sangat tergantung pada kekuatan dan kemandirian desa. Kekuatan dan kemandirian desa akan terwujud jika penganggaran desa benar-benar optimal. Pemerintahan desa di Kabupaten Muna memerlukan perencanaan desa yang baik, sedangkan anggaran desa harus terintegrasi dengan dan berpedoman kepada perencanaan desa dimaksud agar dapat diuji keterkaitan dan konsistensinya dengan prioritas-prioritas dan kepentingan rakyat yang lebih luas.

\section{KAJIAN TEORI}

\section{Kapasitas Penganggaran Desa}

Kapasitas adalah potensi untuk berkinerja (Horton et al, 2003). Lazimnya penggunaan istilah kapasitas ditujukan pada orang dan sistem-sistem kemanusiaan yakni individu, tim, kelompok, organisasi, bangsa, aktor, jaringan kerjasama nasional dan internasional, dan sebagainya. Sebagai konsep, kapasitas seringkali didefinisikan sebagai kemampuan suatu sistem kemanusiaan untuk berkinerja, mempertahankan kelangsungan hidup dan memperbaharui diri Ubels, Acquaye-Baddoo \& Fowler (2010).

Namun, definisi di atas telah dikritik karena tidak memiliki kriteria analitik. Terkait hal itu, Milen (2001) mendefinisikan kapasitas sebagai kemampuan suatu sistem untuk berfungsi sebagaimana mestinya. Istilah "sebagaimana mestinya" menunjukkan bahwa setiap sistem bersifat spesifik atau mempunyai norma spesifik, dalam hal keberfungsian norma memberikan manfaat bagi pencapaian tujuan maka sistem tersebut mempunyai kapasitas. Lebih dari itu, dalam konsep kapasitas tercakup bagaimana input-input dialokasikan dan digunakan untuk memproduksi output dan hasil (GTZ, 2005).

Berdasarkan argumen tersebut, kapasitas penganggaran desa didefinisikan sebagai kemampuan sistem penganggaran desa untuk berfungsi sebagaimana mestinya dalam pengalokasian dan penggunaan input untuk memproduksi output dan hasil yang bermanfaat bagi pencapaian tujuan-tujuan pembangunan desa. Kriteria normatif untuk keberfungsian penganggaran desa dapat dilacak pada peraturan perundang-undangan yang mengaturnya.

\section{Penganggaran Desa}

Penganggaran merupakan fungsi ketujuh dalam POSDCORB Gulick sebagaimana telah disebutkan di muka. Definisi penganggaran sektor publik menurut Allen \& Tommasi (2001) adalah proses dengan mana pemerintah atau suatu organisasi pemerintah merencanakan belanjanya, penerimaannya, pinjamannya dan aktivitas finansial lainnya di masa mendatang. Output dari fungsi penganggaran adalah anggaran. Anggaran di sektor publik disebut anggaran publik atau anggaran pemerintah. Definisi anggaran sektor publik menurut Allen \& Tommasi (2001) adalah suatu dokumen yang mencakup rencana aktivitas finansial masa mendatang dari pemerintah atau suatu organisasi pemerintah. Anggaran pemerintah menurut Simson, Sharma \& Aziz (2011) 
dituangkan dalam perundang-undangan yang diundangkan oleh legislatif, yang memberikan otoritas kepada pemerintah untuk membelanjakan dana-dana menurut ketentuan yang berlaku.

Penganggaran sektor publik terkait dengan proses penentuan jumlah alokasi dana untuk tiap-tiap program dan aktifitas dalam satuan moneter. Pangkey and Pinatik (2015) mengemukakan bahwa penganggaran merupakan suatu proses atau metode untuk mempersiapkan suatu anggaran dengan tahap yang sangat rumit dan mengandung nuansa politik yang kental karena memerlukan pembahasan dan pengesahan dari wakil rakyat di parlemen yang terdiri dari berbagai utusan partai politik. Pada sektor publik, anggaran harus diinformasikan kepada publik untuk dikritik, didiskusikan, dan diberi masukan. Anggaran sektor publik merupakan instrumen akuntabilitas atas pengelolaan dana publik dan pelaksanaan program-program yang dibiayai dengan uang publik.

Penganggaran sektor publik penting karena belanja atau pengeluaran pemerintah tidak dapat dihindari. Penjelasan state-centric institutionalism (Fukuyama, 2009) menegaskan peran negara sebagai fasilitator utama dari solusi atas masalah-masalah publik. Pemerintah menggunakan belanja sebagai instrumen kunci dalam pelaksanaan fungsi alokasi, stabilisasi, dan distribusi. Fungsi alokasi mengandung arti bahwa belanja harus diarahkan untuk mengurangi pengangguran dan pemborosan sumber daya, serta meningkatkan efisiensi dan efektivitas perekonomian. Fungsi distribusi mengandung arti bahwa kebijakan belanja harus memperhatikan rasa keadilan dan kepatutan. Fungsi stabilisasi mengandung arti bahwa belanja pemerintah menjadi alat untuk memelihara dan mengupayakan keseimbangan fundamental perekonomian (Stiglitz, 1988). Jika dimanajemeni dengan baik, belanja pemerintah merefeksikan dengan jelas ke mana perginya uang publik (Denhardt \& Denhardt, 2006). Keberhasilan pemerintah dapat dinilai dari manajemen belanja publiknya karena manajemen belanja publik menunjukkan kebijakan-kebijakannya, prioritas-prioritas dan tindakan-tindakannya, dan transparansi dalam prosedur-prosedur dan informasi anggarannya (Saidahmadovich, 2013).

Output penganggaran di tingkat desa adalah Anggaran Pendapatan dan Belanja Desa, selanjutnya disebut APB Desa. Definisi APB Desa menurut Ketentuan Umum Peraturan Pemerintah Republik Indonesia Nomor 43 Tahun 2014 Tentang Peraturan Pelaksanaan Undang-Undang Nomor 6 Tahun 2014 Tentang Desa adalah rencana keuangan tahunan Pemerintahan Desa. APB Desa ditetapkan dengan Peraturan Desa tentang APB Desa paling lambat tanggal 31 Desember tahun anggaran berjalan. APB Desa terdiri atas: Pendapatan Desa; Belanja Desa; dan Pembiayaan Desa. Pendapatan Desa diklasifikasikan menurut kelompok dan jenis. Belanja Desa diklasifikasikan menurut kelompok, kegiatan, dan jenis. Pembiayaan diklasifikasikan menurut kelompok dan jenis.

\section{Pendekatan untuk Meningkatkan Kapasitas Penganggaran Desa}

Waskitojati dkk. (2016) membahas tiga model perencanaan dan penganggaran partisipatif di desa, yakni: (l) Model perwakilan BPD; (2) Model perlibatan masyarakat di dalam tahapan pembahasan RAPBDesa; dan (3) Model pembahasan RAPBDesa melalui forum konsultasi publik atau musyawarah anggaran desa.

\section{1) Model perwakilan BPD.}

Proses penyusunan APB Desa model perwakilan BPD ini sepenuhnya mengacu kepada regulasi perencanaan dan penganggaran pembangunan desa yang ada yaitu Permendagri Nomor 113 dan 114 Tahun 2014. Tahapantahapan penyusunan APB Desa secara ringkas dapat diuraikan sebagai berikut:

a. Penyusunan Rancangan Peraturan Desa tentang APBDesa oleh Sekretaris Desa;

b. Pembahasan Rancangan Peraturan Desa tentang APBDesa secara bersama antara pemerintah desa dengan BPD;

c. Evaluasi oleh Bupati; dan

d. Penetapan Rancangan Peraturan Desa tentang APBDesa. 
Pada model ini, masyarakat tidak langsung terlibat di dalam pembahasan RAPB Desa, melainkan melalui perwakilan BPD di dalam forum musyawarah pembahasan RAPB Desa. Model perwakilan BPD ini sangat dirasakan manfaatnya pada desa-desa dengan tingkat kesulitan geografis yang tinggi, dimana warga mengalami kesulitan untuk hadir di musyawarah pembahasan anggaran. Anggota BPD sebagai wakil masyarakat desa diharapkan dapat menjadi "jembatan" antara proses-proses yang terjadi di tingkat desa dengan kepentingan warga.

Untuk itu, model ini mensyaratkan BPD yang benar-benar dapat mewakili dan mempunyai rasa empati terhadap kepentingan masyarakat luas. Namun, mekanisme pembentukan BPD melalui musyawarah yang sekarang banyak digunakan terkadang menyebabkan BPD dirasa tidak mewakili masyarakat, sedangkan di sisi lain anggota BPD sendiri merasa tidak memiliki tanggung jawab moral yang kuat terhadap masyarakat. Sehingga tanpa rasa empati dari anggota BPD dan juga tanpa kontrol dari masyarakat, maka model penganggaran "elitis" ini cukup sulit diharapkan dapat menciptakan pembangunan yang dapat benar-benar menjawab kebutuhan desa. Model perwakilan BPD dapat digambarkan sebagai berikut.

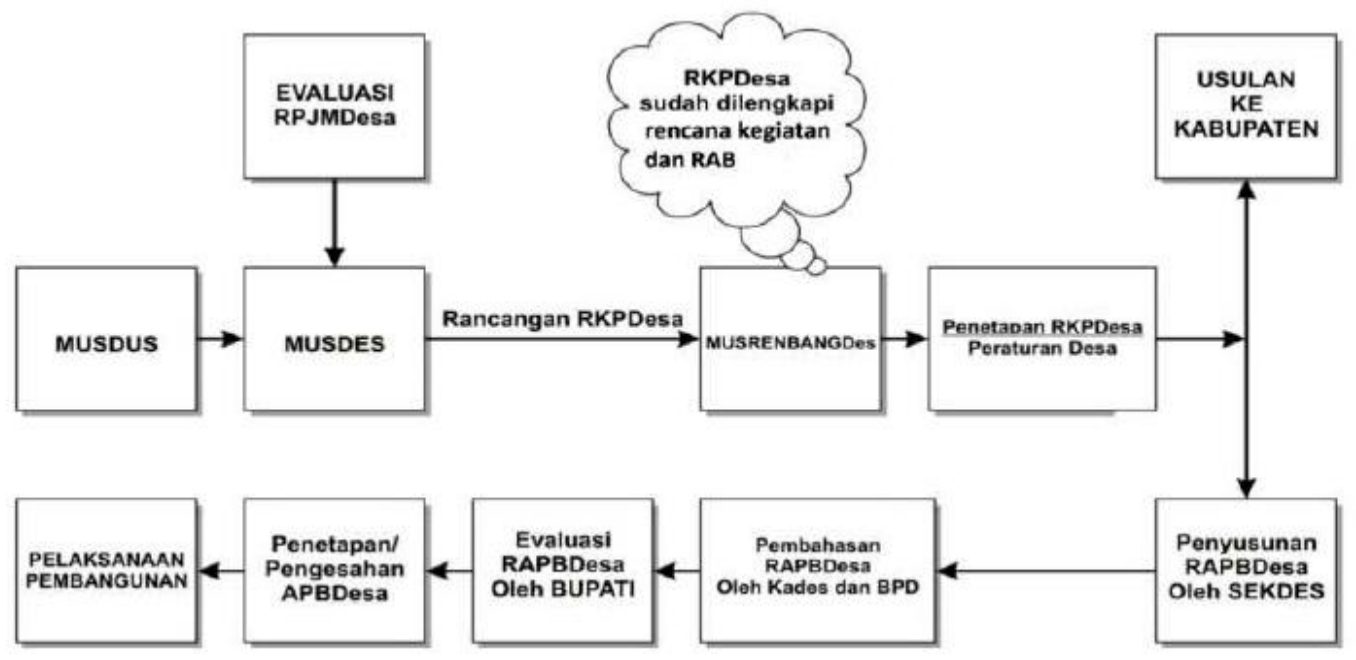

Gambar l. Model perwakilan BPD dalam penyusunan APB Desa

\section{2) Model pelibatan masyarakat dalam tahapan pembahasan RAPB Desa}

Kekuatan dari model ini adalah kebutuhan dukungan pembiayaan yang relatif lebih kecil jika dibandingkan dengan model konsultasi publik. Selain itu masyarakat juga dapat terlibat secara langsung mengawal kesepakatan antara pemerintah desa dan BPD, yang mana hal ini tidak dapat dilakukan di dalam model perwakilan BPD. Di beberapa tempat pengelolaan model ini dilakukan secara berbeda-beda. Ada desa yang melibatkan masyarakat di dalam musyawarah namun tanpa hak suara sehingga masyarakat hanya sebagai penonton saja. Tetapi ada juga desa-desa yang mendorong keterlibatan aktif masyarakat, meski dalam prakteknya, di dalam kultur masyarakat yang feodalistik ataupun mempunyai kesenjangan kapasitas yang tinggi, hal ini cenderung sulit untuk dilakukan. Oleh karenanya model ini lebih berpeluang berjalan dengan baik di daerah-daerah dengan kondisi geografis yang "mudah" dan masyarakat yang egaliter. Namun demikian, keterlibatan masyarakat di dalam pembahasan RAPB Desa seringkali mempunyai nilai keuntungan lebih ketika dibutuhkan pihak netral atau penengah dalam pertarungan politik Kepala Desa dan BPD yang seringkali terbawa ke dalam musyawarah.

\section{3) Model pembahasan RAPB Desa melalui forum konsultasi publik atau musyawarah anggaran desa.}

Model ini ditemui di beberapa wilayah seperti Aceh, Jawa Tengah, Nusa Tenggara Barat dan Sulawesi. Forum konsultasi publik merupakan ruang bagi masyarakat untuk bersama-sama melakukan review dan pembahasan 
rancangan RAPB Desa yang telah disusun oleh sekretaris desa (Sekdes), serta juga melakukan review atas hasil pembahasan antara pemerintah desa dan BPD, jika forum konsultasi publik dilakukan dua kali.

Pada model ini, kemungkinan partisipasi masyarakat berlangsung secara aktif cukup besar mengingat bahwa masyarakat merupakan pihak yang ingin didengar pendapatnya dan juga suasana forum ini relatif lebih egaliter karena masyarakat tidak harus bersaing dengan pemerintah desa ataupun BPD untuk mengutarakan pendapat. Akan tetapi kelemahan dari model ini adalah dalam pelaksanaannya cenderung membutuhkan biaya dan waktu yang lebih besar, serta mempunyai alur yang agak berbeda dengan alur formal dalam Permendagri No. 113 Tahun 2014 sehingga terkadang menimbulkan keragu-raguan pemerintah desa dalam mengadopsi model ini. Hasil review dan saran-saran yang dihasilkan dari forum ini akan menjadi masukan bagi musyawarah pembahasan RAPB Desa oleh pemerintah desa dan BPD.

Di beberapa tempat, konsultasi publik juga dilakukan secara informal di tingkat dusun melalui beberapa kegiatan yang ada di dusun. Sayangnya forum ini tidak cukup terlembaga secara baik sehingga tidak ada jaminan keberlanjutan dan tidak terdokumentasi dengan baik. Pelaksanaan forum konsultasi di tingkat dusun yang terdokumentasi dengan baik bisa dikatakan model yang cukup ideal dalam pengembangan proses penyusunan APBDesa secara partisipatif. Dengan melaksanakannya di tingkat dusun maka ada lebih banyak masyarakat yang dapat terlibat. Selain itu, model ini juga dinilai dapat mengatasi kendala-kendala partisipasi masyarakat yang disebabkan oleh kondisi geografis yang sulit. Model ini digambarkan sebagai berikut:

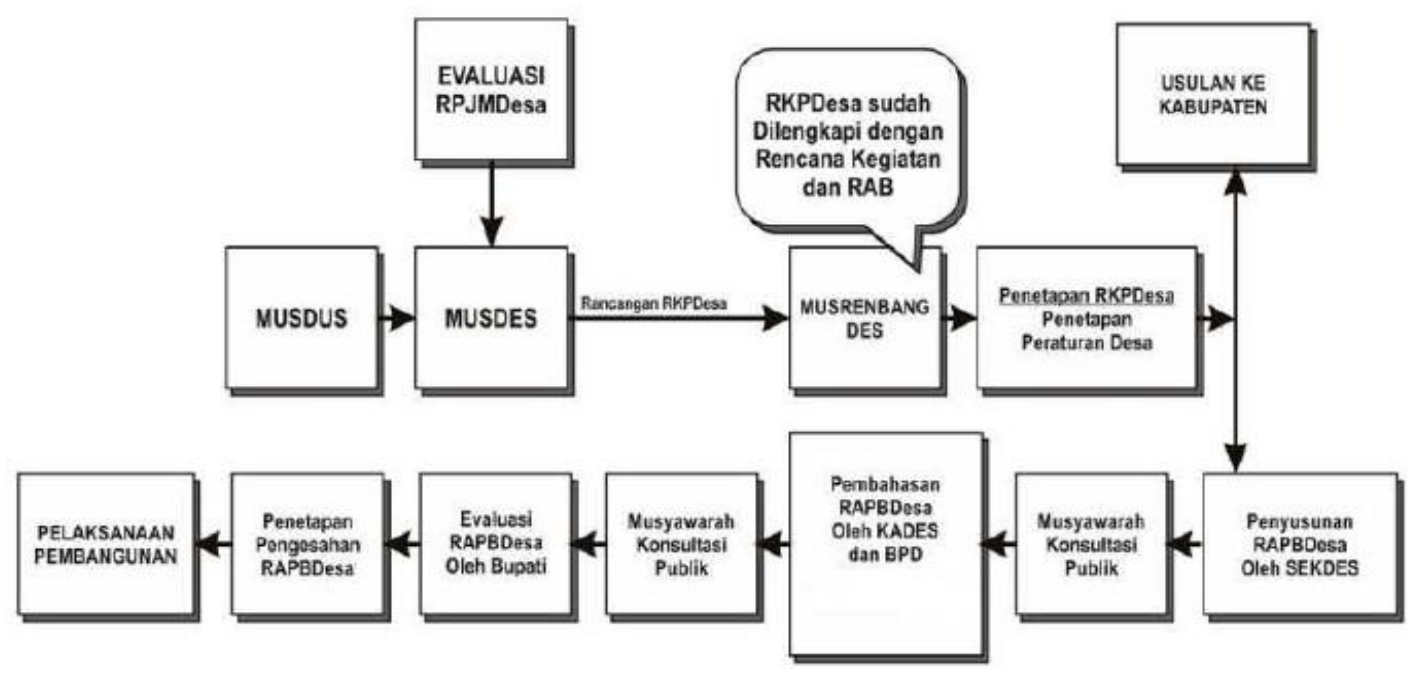

Gambar 3. Model pembahasan RAPB Desa melalui forum konsultasi publik.

Selain ketiga model tersebut, Waskitojati dkk. (2016) mengidentifikasi suatu model alternatif yang dianggap lebih optimal yaitu model pembahasan RAPBDesa di dalam musrenbang desa atau dikenal juga dengan Accidong Sipatangarri (musrenbang desa). Model ini dikembangkan oleh desa Rappoa sejak tahun 2011. Alur dan tahapan dalam Accidong Sipatangarri terdiri dari : FGD Dusun, Musyawarah program desa, Perumusan skala prioritas dan integrasi dengan RPJMDesa, Penyusunan Rencana Penggunaan Anggaran, Rapat Anggaran, Pembuatan Bagan draft RAPBDesa, Accidong Sipatangarri (musrenbang desa), Evaluasi oleh Bupati, Penetapan APBDesa, dan sosialisasi. Di dalam forum musrenbang ini, selain dilakukan penetapan RKPDesa, juga dilakukan pembahasan draft RAPBDesa. Dengan membawa pembahasan draft RAPBDesa ke dalam musrenbang, selain akan menyederhanakan proses perencanaan penganggaran desa, masyarakat secara luas juga dapat terlibat secara langsung di dalam pembahasan anggaran pembangunan desa. Model Accidong Sipatangarri (musrenbang desa) dapat dilihat pada gambar 4. 


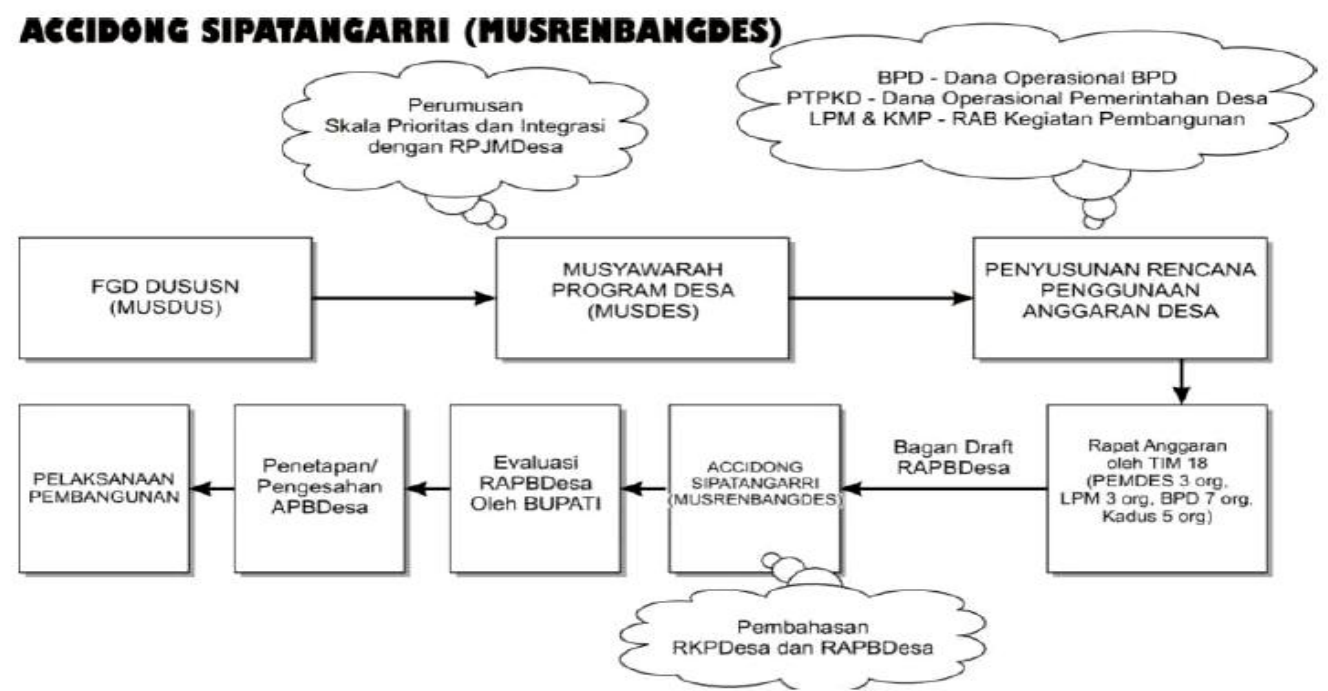

Gambar 4. Model Accidong Sipatangarri (musrenbang desa)

Keuntungan lain dari skema ini adalah ketika ada usulan kegiatan dalam draft RKPDesa yang tidak bisa terakomodir dikarenakan jumlah dana yang tidak mencukupi maka secara langsung bisa disepakati untuk masuk ke dalam prioritas tahun berikutnya. Tantangan model ini yang menggabungkan antara pembahasan RKPDesa dan rancangan RAPBDesa di dalam forum musrenbang desa, adalah waktu yang tersedia untuk mempersiapkan rancangan RAPBDesa sangatlah terbatas. Sehingga kemampuan aktor-aktor pembangunan menjadi salah satu faktor penting bagi keberhasilan pelaksanaan Accidong Sipatangarri ini. Jika diidentifikasi, maka mekanisme partisipatif ini membutuhkan prasyarat-prasyarat pendukung seperti antara lain : (a) kesadaran masyarakat yang tinggi akan pentingnya partisipasi; (b) pengetahuan masyarakat tentang anggaran; (c) ketersediaan informasi besaran dana yang masuk ke desa; dan (d) kapasitas perangkat desa/LPM/Kader dalam menyediakan bahan-bahan yang diperlukan untuk pembahasan anggaran.

Waskitojati dkk. (2016) menyimpulkan bahwa model-model penyusunan APB Desa secara partisipatif yang berkembang di berbagai tempattersebut memberikan kesan kuat bahwa pembangunan desa semakin didekatkan kepada warga sebagai subyek utama penerima manfaat. Warga ditempatkan sebagai pusat perhatian dan selanjutnya dilihat lebih tajam posisinya dalam struktur relasi kekuasaan. Dengan demikian agenda perubahan, sebab UU Desa mempunyai nilai pembaharuan, bukan semata-mata formal-elitis, melainkan menyentuh upaya memperkuat (empowering) warga untuk memiliki kesadaran kritis akan hak-hak untuk terlibat di dalam proses penganggaran pembangunan desa. Ruang-ruang partisipasi yang telah terbuka tersebut tentu akan sia-sia jika tingkat partisipasi masyarakat rendah. Tentu saja penerapan masing-masing model tersebut di atas akan optimal jika sesuai dengan konteksnya. Tidak ada model yang cocok untuk semua konteks sehingga di dalam usaha mengoptimalkan penganggaran desa kita perlu melihat konteks geografis dan sosio-demografisnya.

\section{METODE PENELITIAN}

Penelitian ini menggunakan pendekatan penelitian kualitatif untuk menginvestigasi proses-proses dan output penganggaran desa. Sasaran lokasi studi adalah semua desa di Kabupaten Muna. Berdasarkan data Badan Pusat Statistik Provinsi Sulawesi Tenggara, untuk keadaan tahun 2016, Kabupaten Muna mempunyai 152 desa yang tersebar ke dalam 22 Kecamatan (BPS Provisi Sultra, 2017). Sasaran lokasi studi mencakup semua desa tersebut namun pelaksanaan studi lapang akan difokuskan pada sejumlah desa yang dianggap representatif. Ruang lingkup waktu adalah dua tahun anggaran, yakni tahun 2015-2017. 
Dalam penentuan desa-desa yang dijadikan lokasi studi lapang, tim peneliti berusaha mengkoordinasikan langkah-langkah yang dilakukan dengan berbagai pihak yang berkepentingan dengan maksud untuk dapat memperoleh gambaran makro kontekstual yang komprehensif dan selanjutnya dapat memilih desa-desa yang cukup representatif guna memenuhi tujuan-tujuan studi yang telah ditentukan. Gambaran makro kontekstual untuk menjadi titik tolak studi diperoleh dari aparat Badan Pemberdayaan Masyarakat dan Pemerintahan Desa (BPMPD) Kabupaten Muna, dan Forum Badan Permusyawaratan Desa (F-BAPERDES) Kabupaten Muna. Kedua pihak tersebut dianggap memiliki informasi awal yang mencukupi untuk menentukan langkah-langkah selanjutnya dalam pelaksanaan studi lapang terutama berkenaan dengan kondisi yang ada (existing condition).

Dari diskusi awal dengan para pihak tersebut disepakati untuk terlebih dahulu memetakan desa-desa menurut posisi terhadap laut (desa tepi laut dan desa bukan tepi laut). Pertimbangan utamanya adalah bahwa posisi terhadap laut menjadi pembeda utama aktivitas masyarakat dan pemerintahan desa yang berimplikasi pada penggunaan anggaran desa. Berdasarkan data yang tersedia, Kabupaten Muna mempunyai 69 desa tepi laut dan 83 desa bukan tepi laut. Untuk keperluan studi ditetapkan untuk mengambil 10 persen jumlah desa sehingga lokasi studi ini adalah 7 desa tepi laut dan 8 desa bukan tepi laut dengan pengeluaran rata-rata perkapita pertahun sampai dengan Rp. 7.742.000.

Data yang dibutuhkan dalam penelitian ini adalah tentang proses dan output penganggaran desa. Data tentang proses penganggaran desa akan dilacak dari notulen dan berita acara pembicaraan/rapat perencanaan dan penyusunan anggaran desa. Dari dokumen-dokumen dimaksud akan dikaji tentang bagaimana tahapan prosesnya, siapa yang terlibat dan apa peran utamanya, apa keterbatasan atau kendala yang dihadapi. Selain itu akan digunakan data primer sebagai pelengkap yang diupayakan dari sumber yang kredibel. Data tentang output penganggaran desa akan dilacak dari dokumen keputusan dan peraturan, usulan-usulan, dan laporanlaporan pemerintah desa khususnya dokumen RPJM Desa, RKP Desa, RAPB Desa, APB Desa, dan laporan keuangan pemerintah desa. Menggunakan data dalam dokumen-dokumen tersebut, dilakukan kajian tentang muatan/kapasitasnya.

Untuk tahap pertama ini, data yang dikumpulkan baru mencakup beberapa data profil daerah Kabupaten Muna yang berkenaan dengan perkembangan pemerintahan daerah dan keuangan daerah/desa. Data dimaksud dikumpulkan dari sumber-sumber online dan publikasi resmi Badan Pusat Statistik Provinsi dan Kabupaten. Data yang lebih komprehensif sebagaimana disebutkan pada butir kedua sampai dengan kedelapan akan dikumpulkan pada tahap berikutnya.

Untuk memperoleh data primer, akan ditempuh prosedur konsultasi publik dan/atau diskusi kelompok terfokus. Pada tahap pertama ini, telah dibuat kesepakatan-kesepakatan dengan aparat BPMPD Kabupaten Muna, Pemerintah Desa, dan F-BAPERDES Kabupaten Muna tentang jadwal, lokasi, dan peserta konsultasi publik dan/atau diskusi kelompok terfokus. Kesepakatan yang dicapai adalah:

1) Konsultasi publik dilakukan satu kali, dilaksanakan di BPMPD Kabupaten Muna. Para pihak yang dilibatkan adalah aparat BPMPD Kabupaten Muna, Kepala Seksi Pemerintahan Desa di Kecamatan, FBAPERDES Kabupaten Muna, dan representasi Pemerintah Desa. Materi konsultasi publik digali dan dikembangkan dari hasil-hasil diskusi kelompok terfokus.

2) Diskusi kelompok terfokus dilakukan di tingkat desa, berlokasi pada dua desa yang masing-masing mewakili karakteristik desa sebagaimana telah diuraikan di muka. Para pihak yang dilibatkan dalam dikusi kelompok terfokus adalah Perangkat Desa, anggota Badan Permusyawaratan Desa, dan Lembaga Pemberdayaan Masyarakat Desa.

Data yang tersedia dianalisis dengan prosedur yang sesuai. Data yang diperoleh dari dokumen/usulan dan laporan dianalisis dengan menggunakan prosedur content analysis terutama untuk mengungkap tentang bagaimana tahapan proses perencanaan dan penganggaran desa, siapa yang terlibat dan apa peran utamanya, 
Vol.2 No.2. July 2019. pp.1-19 Copyright@2019 Journal PUBLICUHO Faculty of Social and Political Sciences Halu Oleo University, Kendari, Southeast Sulawesi, Indonesia. e-ISSN: 2621-1351. Open Access at:

http://ojs.uho.ac.id/index.php/PUBLICUHO

Jounal publiuho is licensed under a Creative Commons Attribution 4.0 International License, which permits unrestricted use, distribution, and reproduction in any medium, provided the original work is properly cited.

apa keterbatasan atau kendala yang dihadapi. Prosedur analisis deskriptif diterapkan untuk menganalisis data tentang muatan/kapasitas rencana dan anggaran desa.

\section{HASIL DAN PEMBAHASAN}

\section{Perekonomian Kabupaten Muna}

Perekonomian suatu daerah tergambar melalui Pproduk Domestik Regional Bruto (PDRB) daerah tersebut. PDRB merupakan penjumlahan nilai output bersih (barang dan jasa akhir) yang ditimbulkan oleh seluruh kegiatan ekonomi di suatu wilayah tertentu (Propinsi dan Kabupaten/Kota) dan dalam satu kurun waktu tertentu (satu tahun kalender). Penyajian PDRB dapat disusun dalam dua bentuk, yaitu: PDRB atas dasar harga konstan, dan PDRB atas dasar harga berlaku. PDRB atas dasar harga konstan yaitu jumlah nilai produksi atau pengeluaran atau pendapatan yang dihitung menurut harga tetap. Dari perhitungan ini tercermin tingkat kegiatan ekonomi yang sebenarnya melalui PDRB riilnya. PDRB atas dasar harga konstan ini digunakan untuk mengetahui pertumbuhan tahunan. PDRB atas dasar harga berlaku adalah jumlah nilai tambah bruto dari seluruh sektor perekonomian di suatu wilayah. Nilai tambah yaitu merupakan nilai yang ditambahkan kepada barang dan jasa yang dipakai oleh unit produksi dalam proses produksi sebagai input antara. Nilai yang ditambahkan ini sama dengan balas jasa atas ikut sertanya faktor produksi dalam proses produksi. PDRB atas dasar harga berlaku ini digunakan untuk menunjukkan besarnya suatu perekonomian dan peranan sektorsektor ekonomi.

Nilai PDRB menggambarkan nilai perekonomian suatu daerah. Selanjutnya, untuk melihat struktur perekonomian suatu daerah, kita perlu mencermati sumbangan masing-masing sektor perekonomian terhadap PDRB tersebut atau lazim disebut kontribusi sektoral terhadap pembentukan PDRB. Sektor-sektor yang memberikan kontribusi terbesar terhadap PDRB suatu daerah merupakan cerminan dari struktur perekonomian daerah tersebut. Misalnya, jika kontribusi terbesar terhadap PDRB suatu daerah datang dari sektor industri maka daerah tersebut mempunyai perekonomian industri. Perekonomian Kabupaten Muna bertumpu pada sektor pertanian dan hal ini sekaligus mengkonfirmasi tentang peran strategis desa dalam pembangunan daerah di Kabupaten Muna. Di tahun 2016, sektor pertanian menyumbang sebesar 27,9\% terhadap total PDRB, kontribusi ini menurun dibandingkan tahun 2011 yakni sebesar 33,1\%. Meskipun kontribusinya menurun, tetapi sektor pertanian masih menjadi kontributor terbesar dalam pembentukan PDRB Kabupaten Muna.

\section{Keuangan Daerah Kabupaten Muna}

Keuangan daerah adalah semua hak dan kewajiban daerah yang dapat dimulai dengan uang. Keuangan daerah dikelola dalam format Anggaran dan Pendapatan Belanja Daerah (APBD). APBD adalah rencana keuangan tahunan pemerintahan daerah yang ditetapkan dengan peraturan daerah. APBD terdiri atas tiga komponen, yakni pendapatan, belanja dan pembiayaan. Pendapatan Daerah adalah semua hak Daerah yang diakui sebagai penambah nilai kekayaan bersih dalam periode tahun anggaran yang bersangkutan. Belanja Daerah adalah semua kewajiban Daerah yang diakui sebagai pengurang nilai kekayaan bersih dalam periode tahun anggaran yang bersangkutan. Pembiayaan adalah setiap penerimaan yang perlu dibayar kembali dan/atau pengeluaran yang akan diterima kembali, baik pada tahun anggaran yang bersangkutan maupun pada tahun-tahun anggaran berikutnya. Berikut adalah rincian belanja daerah Kabupaten Muna untuk tahun 2015-2017.

1. Total belanja daerah tahun 2015: Rp 1.161.470.219.650

2. Total belanja daerah tahun 2016: Rp 1.343.210.118.511

3. Total belanja daerah tahun 2017: Rp 1.103.792.105.697

Berdasarkan data tersebut, belanja daerah Kabupaten Muna selama periode 2015-2017 mengalami penurunan. Sebagian dari belanja daerah Kabupaten Muna tersebut dialokasikan untuk desa dalam bentuk Alokasi Dana 
Vol.2 No.2. July 2019. pp.1-19 Copyright@2019. Jo urnal PUBLICUHO Faculty of Social and Political Sciences Halu Oleo University, Kendari, Southeast Sulawesi, Indonesia. e-ISSN: 2621-1351. Open Access at:

Jounal publiuho is licensed under a Creative Commons Attribution 4.0 International License, which permits unrestricted use, distribution, and reproduction in any medium, provided the original work is properly cited.

Desa (ADD) dan Dana Desa (DD). Besaran Alokasi Dana Desa (ADD) dan Dana Desa (DD) di Kabupaten Muna tahun 2015-2017 sebagaimana tertera pada tabel 1 berikut.

Tabel 4.

Besaran ADD dan DD di Kabupaten Muna tahun 2015-2017

\begin{tabular}{cccc}
\hline Tahun & ADD & DD & Total \\
\hline 2015 & 50.437 .502 .000 & 34.213 .502 .000 & 84.651 .004 .000 \\
\hline 2016 & 21.362 .594 .000 & 76.782 .349 .000 & 98.144 .943 .000 \\
\hline 2017 & 68.495 .021 .300 & 97.780 .706 .000 & 166.275 .727 .300 \\
\hline
\end{tabular}

Sumber: Diolah dari APBD Kabupaten Muna Tahun 2015-2017.

\section{Ketersediaan Dokumen Anggaran Pendapatan Belanja Desa (APB Desa)}

Semua desa yang menjadi lokasi penelitian ini mempunyai dokumen APB Desa. Dokumen APB Desa ditetapkan dengan Peraturan Desa (Perdes). Struktur APB Desa di desa-desa lokasi penelitian ini terdiri dari : Pendapatan Desa; Belanja Desa; dan Pembiayaan Desa. Namun demikian, tingkat kerincian uraiannya berbeda pada masing-masing desa. Sebagian desa mempunyai APB Desa yang mencantumkan uraian yang rinci sebagaimana dianjurkan dalam peraturan perundang-undangan, tetapi sebagian lainya mencantumkan hanya yang konkrit sesuai kondisi di desanya.

Pendapatan Desa, berdasarkan ketentuan Pasal 9 sampai dengan 11 Peraturan Menteri Dalam Negeri Republik Indonesia Nomor 113 Tahun 2014 Tentang Pengelolaan Keuangan Desa, diklasifikasikan menurut kelompok dan jenis pendapatan, sebagai berikut: (l). Pendapatan Asli Desa (PADesa), terdiri atas jenis: (a). Hasil usaha; (b). Hasil aset; (c). Swadaya, partisipasi dan gotong royong; dan (d). Lain-lain pendapatan asli desa. (2). Transfer, terdiri atas jenis: (a). Dana Desa; (b). Bagian dari Hasil Pajak Daerah Kabupaten/Kota dan Retribusi Daerah; (c). Alokasi Dana Desa (ADD); (d). Bantuan Keuangan dari APBD Provinsi; dan (e). Bantuan Keuangan APBD Kabupaten/Kota. (3). Pendapatan Lain-Lain, terdiri atas jenis : (a). Hibah dan Sumbangan dari pihak ketiga yang tidak mengikat; dan (b). Lain-lain pendapatan Desa yang sah.

Hasil studi lapang menunjukkan bahwa dalam semua dokumen APB Desa di semua desa yang diteliti, untuk tahun anggaran 2015-2017, pada Lampiran APB Desa, yang dicantumkan di bawah "Pendapatan" bervariasi. Dalam sebagian APB Desa tercantum tiga kelompok pendapatan, yakni PADesa, Transfer, dan Pendapatan Lain-Lain. Dalam sebagian APB Desa tercantum hanya PADesa dan Transfer. Akan tetapi, di semua APB Desa yang mencantumkan Pendapatan Lain-Lain, tidak mengisi jumlah nominal anggarannya atau dikosongkan saja. Bagi desa-desa yang APB Desanya tidak mencantumkan Pendapatan Lain-Lain juga tidak mengalami hambatan dalam perolehan pengesahan APB Desa oleh pejabat di Kabupaten.

Jenis pendapatan yang tercantum di bawah masing-masing kelompok pendapatan bervariasi. Dalam sebagian APB Desa tercantum uraian jenis pendapatan asli desa sebagaimana yang disebutkan dalam Peraturan Menteri Dalam Negeri Nomor 113 Tahun 2014 Tentang Pengelolaan Keuangan Desa, walaupun hanya sebagian saja yang terisi anggarannya. Sebagian APB Desa yang lain hanya mencantumkan dua jenis pendapatan asli desa yakni: (1) swadaya, partisipasi dan gotong royong, dan (2) lain-lain pendapatan asli desa. Tidak ada desa yang menganggarkan penerimaan dari hasil usaha dan hasil aset desa. Namun demikian, di beberapa desa lokasi penelitian, saat penelitian ini berlangsung, telah dibicarakan dan dicapai kesepakatan-kesepakatan antara Pemerintah Desa dan BPD prihal Bumdes sehingga dalam APB Desa tahun 2017 dan ke depannya sudah dapat dianggarkan.

Untuk kelompok pendapatan transfer, dalam sebagian APB Desa tercantum seluruh jenis pendapatan sebagaimana yang disebutkan dalam Peraturan Menteri Dalam Negeri Nomor 113 Tahun 2014 Tentang Pengelolaan Keuangan Desa, walaupun hanya sebagian juga yang terisi anggarannya. Tidak ada APB Desa 
yang menganggarkan "Bagian dari Hasil Pajak Daerah Kabupaten/Kota dan Retribusi Daerah". Tidak ada juga kejelasan bahwa di tahun-tahun mendatang desa akan memperoleh pendapatan dari sumber tersebut.

Untuk kelompok Pendapatan Lain-Lain, dalam sebagian APB Desa tercantum seluruh jenis pendapatan lainlain sebagaimana yang disebutkan dalam Peraturan Menteri Dalam Negeri Nomor 113 Tahun 2014 Tentang Pengelolaan Keuangan Desa, walaupun tidak ada yang terisi nominal anggarannya. Tidak ada desa yang menganggarkan pendapatan lain-lain baik dari Hibah dan Sumbangan dari pihak ketiga yang tidak mengikat, maupun Lain-lain pendapatan Desa yang sah. Walaupun dalam sebagian APB Desa tidak tercantum Pendapatan Lain-Lain tetapi tidak ada hambatan dalam verifikasi Perdes tentang APB Desa tersebut.

Belanja Desa, berdasarkan ketentuan Pasal 12 sampai dengan 17 Peraturan Menteri Dalam Negeri Nomor 113 Tahun 2014 Tentang Pengelolaan Keuangan Desa, diklasifikasikan menurut kelompok belanja, sebagai berikut: (a). Penyelenggaraan Pemerintahan Desa; (b). Pelaksanaan Pembangunan Desa; (c). Pembinaan Kemasyarakatan Desa; (d). Pemberdayaan Masyarakat Desa; dan (e). Belanja Tak Terduga. Masing-masing Kelompok Belanja sebagaimana dimaksud dibagi dalam Kegiatan sesuai dengan kebutuhan Desa yang telah dituangkan dalam RKP Desa di mana Kegiatan sebagaimana dimaksud terdiri atas tiga jenis belanja, yakni:

1) Belanja Pegawai, dianggarkan untuk pengeluaran penghasilan tetap dan tunjangan bagi Kepala Desa dan Perangkat Desa serta tunjangan BPD, dianggarkan dalam kelompok Penyelenggaraan Pemerintahan Desa, kegiatan pembayaran penghasilan tetap dan tunjangan;

2) Belanja Barang dan Jasa, digunakan untuk pengeluaran pembelian/pengadaan barang yang nilai manfaatnya kurang dari 12 (dua belas) bulan; dan

3) Belanja Modal, digunakan untuk pengeluaran dalam rangka pembelian/pengadaan barang atau bangunan yang nilai manfaatnya lebih dari 12 (dua belas) bulan, untuk kegiatan penyelenggaraan kewenangan desa.

Hasil studi lapang menunjukkan bahwa dalam semua dokumen APB Desa di semua desa yang diteliti, untuk tahun anggaran 2015- 2017, tercantum "Belanja Desa" dengan perincian menurut kelompok belanja yang bervariasi. Sebagian desa mencantumkan hanya empat kelompok belanja sebagai berikut:

a. Bidang Penyelenggaraan Pemerintahan Desa;

b. Bidang Pelaksanaan Pembangunan Desa;

c. Bidang Pembinaan Kemasyarakatan Desa; dan

d. Bidang Pemberdayaan Masyarakat Desa.

Sebagian desa yang lain mencantumkan lima kelompok belanja, di mana selain empat kelompok tersebut di atas masih ditambah dengan "Belanja Tak Terduga". Akan tetapi, dalam kelompok "Belanja Tak Terduga" ini ada yang terisi dan ada pula yang tidak terisi nominal anggarannya. Sebagian informan di pemerintah desa mengatakan bahwa, berdasarkan petunjuk yang diperolehnya dari pejabat yang berwenang di kabupaten, kelompok "Belanja Tak Terduga" boleh dicantumkan boleh juga tidak, tetapi sebagian informan lain menyatakan bahwa dalam struktur belanja harus tetap dicantumkan kelompok "Belanja Tak Terduga", walaupun nilai nominalnya boleh dikosongkan. Faktanya, sebagian desa mencantumkan kelompok belanja tak terduga walaupun tanpa nilai nominal, tetapi desa-desa yang tidak mencantumkanpun tidak mengalami hambatan dalam verifikasi Perdes tentang APB Desanya.

Pembiayaan Desa, berdasarkan ketentuan Pasal 18 sampai dengan 19 Peraturan Menteri Dalam Negeri Nomor 113 Tahun 2014 Tentang Pengelolaan Keuangan Desa, diklasifikasikan menjadi dua kelompok, yakni:

a. Penerimaan Pembiayaan, terdiri atas;

1) Sisa lebih perhitungan anggaran (SiLPA) tahun sebelumnya;

2) Pencairan Dana Cadangan; dan

3) Hasil penjualan kekayaan desa yang dipisahkan.

b. Pengeluaran Pembiayaan, terdiri dari:

1) Pembentukan Dana Cadangan; dan

2) Penyertaan Modal Desa. 
Hasil studi lapang menunjukkan bahwa dalam semua dokumen APB Desa di semua desa yang diteliti, untuk tahun anggaran 2015 dan 2016, tercantum kelompok pembiayaan, yakni Penerimaan Pembiayaan dan Pengeluaran Pembiayaan, tetapi rincian jenis Penerimaan Pembiayaan dan Pengeluaran Pembiayaan tersebut bervariasi. Pada sebagian APB Desa, tercantum semua rincian Penerimaan Pembiayaan dan Pengeluaran Pembiayaan, pada sebagian lainnya tercantum sebagian saja rinciannya. Pada sebagian APB Desa yang mencantumkan semua rincian Penerimaan Pembiayaan, tidak satupun yang menganggarkan Penerimaan Pembiayaan, jadi hanya judulnya saja yang dicantumkan. Pada sebagian APB Desa yang mencantumkan semua rincian Pengeluaran Pembiayaan, hanya sebagian yang menganggarkan, yakni pada penyertaan modal desa. Meskipun dalam APB Desa tidak tercantum rincian penerimaan pembiayaan dan pengeluaran pembiayaan tetapi tidak ada hambatan dalam verifikasi Perdes tentang APB Desa.

Perdes tentang APB Desa, berdasarkan ketentuan Pasal 20 Peraturan Menteri Dalam Negeri Nomor 113 Tahun 2014 Tentang Pengelolaan Keuangan Desa, disepakati bersama oleh Kepala Desa dan Badan Permusyawaratan Desa paling lambat bulan Oktober tahun berjalan. Di desa-desa yang menjadi lokasi penelitian ini, kesepakatan bersama oleh Kepala Desa dan Badan Permusyawaratan Desa bervariasi, tetapi yang paling dominan adalah setelah bulan Oktober, yakni minggu kedua dan minggu ketiga bulan November. Hanya di sebagian kecil desa saja kesepakatan atas APB Desa oleh Kepala Desa dan Badan Permusyawaratan Desa dicapai pada minggu keempat bulan Oktober. Keterlambatan ini terjadi sebagai kontingensi dari penyampaian tentang ketersediaan anggaran yang juga lambat dilakukan. Sebagai contoh, untuk tahun anggaran 2015 penyampaian informasi anggaran ADD dari kabupaten ke Desa dilakukan pada bulan Agustus, untuk tahun anggaran 2016 penyampaian informasi anggaran ADD dilakukan pada bulan awal Juli sedangkan informasi anggaran DD disampaikan pada akhir bulan Juli. Hal ini menunjukkan bahwa ketentuan waktu tentang kesepakatan atas APB Desa oleh Kepala Desa dan Badan Permusyawaratan Desa belum dilaksanakan sebagaimana mestinya.

\section{Ketersediaan Dokumen Rencana Anggaran Biaya (RAB).}

Semua desa yang diteliti mempunyai dokumen Rencana Anggaran Biaya (RAB). Dalam dokumen RAB tertera nama dan tanda tangan Pelaksana Kegiatan, pejabat yang melakukan verifikasi (dalam hal ini Sekretaris Desa), dan pejabat yang mengesahkan (dalam hal ini Kepala Desa). Setiap jenis kegiatan diuraikan dalam format RAB tersendiri. Misalnya, RAB kegiatan pembayaran penghasilan tetap dan tunjangan, pada bidang penyelenggaraan pemerintahan desa, diuraikan dalam lembar tersendiri, terpisah misalnya dengan kegiatan operasional kantor desa, kegiatan operasional BPD, dan kegiatan lain yang termasuk bidang penyelenggaraan pemerintahan desa. Demikian juga, RAB kegiatan pembangunan sarana dan prasarana fisik sosial, diuraikan dalam lembar tersendiri, demikian seterusnya untuk seluruh bidang-bidang lainnya.

Dalam uraian anggaran pada semua lembar RAB tercantum volume, harga satuan, dan jumlah anggaran. Akan tetapi, volume maupun harga satuan yang dicantumkan bersifat sangat umum. Misalnya, dalam RAB kegiatan pembangunan sarana dan prasarana fisik, volume dituliskan l paket, sedangkan harga satuan dituliskan total harga untuk satu paket tersebut sehingga sama isinya dengan kolom jumlah aggaran. Demikian juga, dalam RAB kegiatan belanja barang dan jasa untuk bantuan anak dan remaja, volume tertulis satu paket, dan harga satuan tertulis 2.000.000. Pencatatan seperti ini tentu memerlukan teknik verifikasi yang akurat dan detail sebelum disetujui dan disahkan. Namun, informan penelitian yang diwawancarai mengatakan bahwa tidak ada kendala untuk memperoleh pengesahan RAB.

\section{Proses Penyusunan APB Desa}

Dokumen anggaran desa, yakni APB Desa sebagaimana diuraikan di atas, merupakan output dari proses penyusunan anggaran desa. Proses penyusunan APB Desa yang dianjurkan dalam Peraturan Menteri Dalam Negeri Nomor 113 Tahun 2014 Tentang Pengelolaan Keuangan Desa adalah: (1) Kepala Desa menetapkan 
Vol.2 No.2. July 2019. pp.1-19 Copyright@2019 Journal PUBLICUHO Faculty of Social and Political Sciences Halu Oleo University, Kendari, Southeast Sulawesi, Indonesia. e-ISSN: 2621-1351. Open Access at:

http://ojs.uho.ac.id/index.php/PUBLICUHO

Jounal publiuho is licensed under a Creative Commons Attribution 4.0 International License, which permits unrestricted use, distribution, and reproduction in any medium, provided the original work is properly cited.

Keputusan Kepala Desa tentang Pelaksana Teknis Pengelolaan Keuangan Desa (PTPKD); (2) Sekretaris Desa selaku koordinator PTPKD menyusun Ranperdes tentang APB Desa; (3) Kepala Seksi sebagai pelaksana kegiatan sesuai dengan bidangnya menyusun rencana pelaksanaan kegiatan yang menjadi tanggung jawabnya; (4) Sekretaris Desa menyampaikan Ranperdes tentang APB Desa kepada Kepala Desa; (5) Ranperdes tentang APB Desa sebagaimana dimaksud disampaikan oleh Kepala Desa kepada Badan Permusyawaratan Desa untuk dibahas dan disepakati bersama; (6) Ranperdes tentang APB Desa yang telah disepakati bersama disampaikan oleh Kepala Desa kepada Bupati melalui Camat untuk dievaluasi; (7) Bupati dapat mendelegasikan evaluasi Ranperdes tentang APB Desa kepada Camat; (8) Pelaksana kegiatan mengajukan pendanaan untuk melaksanakan kegiatan disertai dengan dokumen Rencana Anggaran Biaya; dan (9) Rencana Anggaran Biaya diverifikasi oleh Sekretaris Desa dan disahkan oleh Kepala Desa.

Semua desa yang diteliti mempunyai PTPKD yang ditetapkan dengan Keputusan Kepala Desa. Personil PTPKD terdiri atas Sekretaris Desa selaku koordinator PTPKD, Kepala Seksi sebagai pelaksana kegiatan, dan staf pada Urusan Keuangan sebagai Bendahara. Sedikit perbedaan dengan ketentuan Pasal 6 Peraturan Menteri Dalam Negeri Nomor 113 Tahun 2014 Tentang Pengelolaan Keuangan Desa adalah, di mana ditegaskan bahwa Kepala Seksi bertindak sebagai pelaksana kegiatan sesuai dengan bidangnya, tetapi di sebagian desa lokasi penelitian ini Kepala Seksi bertindak sebagai pelaksana kegiatan yang tidak sesuai dengan bidangnya.

Kondisi di atas terjadi karena nomenklatur Seksi (Pelaksana Teknis) tidak persis sama dengan klasifikasi kelompok belanja desa. Susunan organisasi Pelaksana Teknis Pemerintah Desa berdasarkan Peraturan Menteri Dalam Negeri Republik Indonesia Nomor 84 Tahun 2015 Tentang Susunan Organisasi Dan Tata Kerja Pemerintah Desa terdiri dari: Seksi Pemerintahan, Seksi Kesejahteraan, dan Seksi Pelayanan, atau paling sedikit terdiri dari Seksi Pemerintahan, dan Seksi Kesejahteraan dan Pelayanan. Sementara, klasifikasi belanja desa berdasarkan Peraturan Menteri Dalam Negeri Nomor 113 Tahun 2014 Tentang Pengelolaan Keuangan Desa terdiri atas kelompok: Penyelenggaraan Pemerintahan Desa, Pelaksanaan Pembangunan Desa, Pembinaan Kemasyarakatan Desa, dan Pemberdayaan Masyarakat Desa.

Sebagai respons terhadap perbedaan tersebut di atas maka Kepala Desa membuat penafsiran sendiri tentang kesesuaian bidang. Di sebagian desa, pelaksana kegiatan tertentu pada Bidang Pemberdayaan Masyarakat ataupun Bidang Pembinaan Kemasyarakatan Desa dipegang oleh Kepala Seksi Pemerintahan. Lagi pula, di sebagian desa, ada Kepala Seksi yang tidak menjadi pelaksana kegiatan dalam satu tahun anggaran, termasuk kegiatan-kegiatan yang sesuai dengan tugas pokoknya dalam struktur organisasi pemerintah desa. Akan tetapi, tidak ada kendala dalam proses verifikasi terkait kesesuaian usulan kegiatan dimaksud, usulan kegiatan tetap mendapat persetujuan dan pengesahan.

Kepala Seksi yang diwawancarai, yang tidak menjadi pelaksana kegiatan di desanya, menyatakan tidak keberatan dengan keadaan tersebut, ia menerima saja keadaannya karena sadar bahwa dalam waktu yang tidak lama lagi ia juga akan diganti dari jabatan sebagai Kepala Seksi karena terkait dengan kiprahnya dalam pemilihan kepala desa yang lalu di mana ia tidak mendukung kepala desa yang ada sekarang. Kepala Desa yang diwawancarai menyatakan bahwa penempatan personalia PTPKD sudah dikonsultasikan dengan pejabat yang berwenang di BPMPD Kabupaten dan tidak ada masalah dengan penempatan silang tersebut.

Pelaksanaan tugas Sekretaris Desa selaku koordinator PTPKD dalam penyusunan Ranperdes tentang APB Desa di desa-desa lokasi penelitian ini bervariasi. Di sebagian desa, Sekretaris Desa yang mengurus penyusunan Ranperdes tentang APB Desa. Walaupun dalam prakteknya penyusunan tersebut dilakukan oleh pihak lain, tetapi Sekretaris Desa yang mengupayakannya. Di sebagian desa lainnya, Sekretaris Desa tidak melakukan dan tidak mengurus penyusunan Ranperdes tentang APB Desa, tetapi bertandatangan dalam kapasitasnya selaku koordinator. Adapun yang mengurus penyusunan Ranperdes tentang APB Desa adalah Kepala Desa dengan bantuan pihak lain. Pihak lain ini bukan pendamping lokal desa, bukan juga Pendamping Desa sebagaimana disebutkan dalam peraturan perundang-undangan. Beberapa informan mengatakan bahwa penyusunan Ranperdes tentang APB Desa dilakukan oleh orang yang sama dengan yang menyusun RKP Desa 
dan RPJM Desa, yakni pejabat di Kabupaten. Akan tetapi, informasi ini tidak dapat dikonfirmasi karena Kepala Desa yang diwawancarai tidak bersedia memberikan informasi.

Pelaksanaan tugas Kepala Seksi sebagai pelaksana kegiatan sesuai dengan bidangnya dalam penyusunan rencana pelaksanaan kegiatan di desa-desa lokasi penelitian ini bervariasi. Di sebagian desa di mana Kepala Seksi masuk dalam PTPKD, Kepala Seksi dimaksud mengurus penyusunan rencana pelaksanaan kegiatan, bukan membuat sendiri tetapi mencari orang yang dapat membantu menyusun. Di sebagian desa lainnya, Kepala Seksi tidak mengurus penyusunan rencana pelaksanaan kegiatan. Walau demikian, baik Kepala Seksi yang ikut mengurus maupun yang tidak ikut mengurus penyusunan rencana pelaksanaan kegiatan, tetap saja bertanda tangan dalam kedudukannya sebagai pelaksana kegiatan. Informasi yang diperoleh menyatakan bahwa yang menyusun rencana pelaksanaan kegiatan bukan pendamping lokal desa, bukan juga Pendamping Desa, tetapi orang yang sama dengan yang menyusun RKP Desa dan RPJM Desa serta Ranperdes tentang APB Desa. Akan tetapi, informasi ini tidak dapat dikonfirmasi karena Kepala Desa dan Kepala Seksi yang diwawancarai tidak bersedia memberikan informasi.

Secara formal, penyampaian Ranperdes tentang APB Desa oleh Sekretaris Desa (selaku Koordinator PTPKD) kepada Kepala Desa tidak dilaksanakan di semua desa yang menjadi lokasi penelitian ini. Di semua desa, penyerahan dilakukan secara langsung secara informal, tidak ada surat resmi penyampaian. Sementara itu di beberapa desa lainnya di mana Sekretaris Desa sama sekali tidak diperankan dalam penyusunan Ranperdes tentang APB Desa atau minimal dalam pengurusannya, tidak ada penyerahan Ranperdes tentang APB Desa baik secara formal maupun informal. Kepala Desa dan Sekretaris Desa yang diwawancarai menyatakan bahwa penyampaian Ranperdes tentang APB Desa melalui surat formal tidak terlalu penting untuk diperhatikan karena hal itu hanyalah persoalan teknis prosedural yang tidak mempunyai konsekuensi terhadap proses-proses berikutnya.

Penyampaian Ranperdes tentang APB Desa oleh Kepala Desa kepada Badan Permusyawaratan Desa untuk dibahas dan disepakati bersama di desa-desa lokasi penelitian ini mengambil tiga bentuk. Pertama, di sebagian kecil desa, Kepala Desa menyampaikan secara formal Ranperdes tentang APB Desa kepada BPD. Setelah menerima Ranperdes tentang APB Desa, BPD menyiapkan dan melaksanakan rapat untuk membahas, lalu BPD menerbitkan keputusan BPD tentang persetujuan APB Desa yang ditandatangani oleh BPD dan Kepala Desa. Kedua, di sebagian besar desa, Kepala Desa menyampaikan secara formal Ranperdes tentang APB Desa kepada BPD namun BPD dan Kepala Desa tidak menyelenggarakan rapat formal untuk membahas dan menyepakati bersama. Yang ada hanyalah pertemuan informal Kepala Desa dengan sebagian BPD, tetapi ada dokumen keputusan BPD tentang persetujuan APB Desa. Meskipun pertemuannya informal tetapi ada daftar hadir rapat yang ditandatangani oleh Ketua dan sebagian anggota BPD. Ketiga, Kepala Desa tidak menyampaikan kepada dan membahas Ranperdes tentang APB Desa dengan BPD. Namun, tetap ada dokumen keputusan BPD tentang persetujuan APB Desa. Dokumen keputusan BPD tentang persetujuan APB Desa sudah disiapkan terlebih dahulu oleh Kepala Desa, kemudian dimintakan tanda tangan persetujuan dan daftar hadir ketua dan anggota BPD.

Desa-desa yang menerapkan pola pertama menggambarkan kondisi dimana hubungan kemitraan antara Kepala Desa dan BPD sudah berjalan sebagaimana mestinya. Namun, pola ini ditemukan hanya di dua desa sampel. Ketua BPD yang diwawancarai mengemukakan bahwa masing-masing pihak sudah saling memahami kedudukan dan tugas sehingga tidak ada kendala dalam komunikasi tugas. Akan tetapi pola ini diterapkan hanya dalam penyusunan Ranperdes tentang PB Desa, tidak diterapkan dalam penyusunan RPJM Desa dan RKP Desa. Desa-desa yang menerapkan pola kedua dan ketiga mempunyai kemiripan, komunikasi tugas antara BPD dengan Kepala Desa tersendat, tetapi ada kekuatan di atas desa yang dapat menggiring keduanya untuk sama-sama mengesahkan dokumen yang diperlukan bagi kelancaran pencairan dana, yakni dokumen keputusan BPD tentang persetujuan APB Desa dan Penetapan Raperdes menjadi Perdes APB Desa. 
Vol.2 No.2. July 2019. pp.1-19 Copyright@2019 Journal PUBLICUHO Faculty of Social and Political Sciences Halu Oleo University, Kendari, Southeast Sulawesi, Indonesia. e-ISSN: 2621-1351. Open Access at:

http://ojs.uho.ac.id/index.php/PUBLICUHO

Jounal publiuho is licensed under a Creative Commons Attribution 4.0 International License, which permits unrestricted use, distribution, and reproduction in any medium, provided the original work is properly cited.

Informan penelitian yang diwawancarai menyatakan bahwa setelah disediakan draftnya, BPD dipanggil ke Kabupaten atau dihubungi oleh pejabat di Kabupaten untuk menandatangani. Informan lain menyatakan bahwa setelah tersedia draft, Kepala Desa yang menemui BPD untuk meminta tanda tangan setelah ada arahan dari Kabupaten. Namun demikian, kedua informasi ini tidak dapat dikonfirmasi karena informan tersebut tidak bersedia memberikan identitas pejabat di Kabupaten yang dimaksudkan. Sementara itu, pengurus BPD yang diwawancarai menyatakan tidak mempersoalkan ada tidaknya rapat untuk melakukan pembahasan dan persetujuan bersama dengan Kepala Desa karena BPD sendiri kurang memiliki keterampilan teknis untuk membaca struktur anggaran, lagi pula BPD tidak mempunyai dokumen-dokumen peraturan yang dapat dijadikan landasan untuk membahas rancangan APB Desa yang telah disiapkan oleh Kepala Desa. Selain itu, rancangan APB Desa yang telah disiapkan oleh Kepala Desa dianggap cukup karena dalam penyusunannya Kepala Desa telah mendapat bimbingan dan arahan dari pihak-pihak yang memahami teknis penyusunannya.

Sesuai ketentuan pasal 21 Peraturan Menteri Dalam Negeri Nomor 113 Tahun 2014 Tentang Pengelolaan Keuangan Desa, Ranperdes tentang APB Desa yang telah disepakati bersama BPD disampaikan oleh Kepala Desa kepada Bupati melalui Camat untuk dievaluasi. Selanjutnya, sesuai ketentuan pasal 23 Peraturan Menteri Dalam Negeri Nomor 113 Tahun 2014 Tentang Pengelolaan Keuangan Desa, Bupati dapat mendelegasikan evaluasi Ranperdes tentang APB Desa kepada Camat. Praktiknya di desa-desa lokasi penelitian ini, penyampaian Ranperdes tentang APB Desa yang telah disepakati bersama BPD kepada Bupati tidak melalui Camat. Selain itu, Camat tidak pernah mendapat pendelegasian tugas untuk melakukan evaluasi terhadap Rancangan Perdes tentang APB Desa.

Tidak adanya pendelegasian tugas kepada camat, menurut informan penelitian, dikarenakan belum ada peraturan bupati tentang tata cara pendelegasian pelaksanaan evaluasi Ranperdes tentang APB Desa kepada Camat. Sementara itu, Camat yang diwawancarai menyatakan bahwa di wilayah tugasnya tidak ada penyampaian Ranperdes tentang APB Desa kepada Bupati yang melalui Camat, Kepala Desa langsung menyampaikannya kepada Bupati melalui BPMPD. Oleh karena penyampaiannya tidak melalui Camat maka di Kecamatan tidak tersedia dokumen berupa Rancangan APB Desa. Lagi pula, Kepala Desa tidak pernah meminta konsultasi kepada Camat berkenaan dengan penyusunan Rancangan APB Desa, Kepala Desa dalam menyusun Rancangan APB Desa hanya berhubungan dengan BPMPD Kabupaten.

Camat di lokasi penelitian ini sebenarnya berharap dapat memainkan peran yang konkrit dalam proses evaluasi Rancangan APB Desa, bahkan dalam evaluasi Rancangan RPJM Desa dan Rancangan RKP Desa, guna merealisasikan amanat Undang-Undang Nomor 23 Tahun 2014 tentang Pemerintahan Daerah. Sesuai pasal 221 Undang-Undang tersebut, Daerah kabupaten/kota membentuk Kecamatan dalam rangka meningkatkan koordinasi penyelenggaraan pemerintahan, pelayanan publik, dan pemberdayaan masyarakat Desa/kelurahan. Selanjutnya, tugas-tugas Camat diatur pada Pasal 225 sebagai berikut: (a) menyelenggarakan urusan pemerintahan umum; (b) mengoordinasikan kegiatan pemberdayaan masyarakat; (c) mengoordinasikan upaya penyelenggaraan ketenteraman dan ketertiban umum; (d) mengoordinasikan penerapan dan penegakan Perda dan Perkada; (e) mengoordinasikan pemeliharaan prasarana dan sarana pelayanan umum; (f) mengoordinasikan penyelenggaraan kegiatan pemerintahan yang dilakukan oleh Perangkat Daerah di Kecamatan; (g) membina dan mengawasi penyelenggaraan kegiatan Desa dan/atau kelurahan; (h) melaksanakan Urusan Pemerintahan yang menjadi kewenangan Daerah kabupaten/kota yang tidak dilaksanakan oleh unit kerja Perangkat Daerah kabupaten/kota yang ada di Kecamatan; dan (i) melaksanakan tugas lain sesuai dengan ketentuan peraturan perundang-undangan. Jika penyampaian Rancangan APB Desa oleh Kepala Desa kepada Bupati dilakukan melalui Camat maka tentunya Camat dapat mengoordinasikan, membina dan mengawasi penyelenggaraan kegiatan Desa.

Di sisi yang lain, sebagian Kepala Desa dan BPD beranggapan bahwa penyampaian Rancangan APB Desa oleh Kepala Desa kepada Bupati yang harus melalui Camat adalah tidak efisien dan hanya memperlambat proses evaluasi. Camat dapat saja berbeda pendapat dengan Bupati dan instansi teknis Kabupaten dalam hal ini 
Jounal publiuho is licensed under a Creative Commons Attribution 4.0 International License, which permits unrestricted use, distribution, and reproduction in any medium, provided the original work is properly cited.

BPMPD. Kalau terjadi perbedaan, tentu pendapat Bupati yang harus diikuti. Lagi pula, Kecamatan mempunyai kedudukan yang setara dengan BPMPD. Sesuai ketentuan pasal 209 Undang-Undang Nomor 23 Tahun 2014 tentang Pemerintahan Daerah, Pangkat Daerah kabupaten/kota terdiri atas: sekretariat daerah, sekretariat DPRD, inspektorat, dinas, badan, dan Kecamatan. Jadi, tidak efektif dan tidak etis jika penyampaian Rancangan APB Desa harus melalui Camat, sedangkan di Kabupaten ada lembaga teknis yang membidangi pemberdayaan pemerintahan desa yakni BPMPD.

Hasil evaluasi terhadap Rancangan Perdes tentang APB Desa oleh Bupati menentukan apakah Rancangan Perdes tentang APB Desa dapat atau tidak dapat ditetapkan menjadi Perdes tentang APB Desa. Dalam hal Bupati menyatakan sudah sesuai maka Kepala Desa menetapkan Rancangan Perdes tentang APB Desa menjadi Perdes tentang APB Desa dan dapat diimplementasikan. Pada tahap implementasi, Pelaksana Kegiatan mengajukan pendanaan untuk melaksanakan kegiatan disertai dengan dokumen Rencana Anggaran Biaya. Usulan pendanaan diverifikasi oleh Sekretaris Desa dan disahkan oleh Kepala Desa.

Dalam praktik hanya sebagian kecil dari desa-desa lokasi penelitian ini yang pengajuan pendanaan untuk melaksanakan kegiatan dilakukan oleh Pelaksana Kegiatan. Hal ini tidak berarti bahwa tidak ada pengajuan $R A B$, ada pengajuan RAB tetapi yang mengajukan bukan Pelaksana Kegiatan sebagaimana tertera dalam dokumen RAB. Informan penelitian mengemukakan bahwa sebagian besar dari Pelaksana Kegiatan yang tertera namanya dalam RAB hanya formalitas, sebenarnya yang melaksanakan secara riil adalah Kepala Desa sendirian, atau Kepala Desa bersama Sekretaris Desa. Di sebagian besar desa lokasi penelitian, Kepala Seksi yang ditunjuk menjadi Pelaksana Kegiatan hanya di atas kertas saja atau formalitas, mereka menandatangani dokumen $R A B$ tetapi menyimpan dan mengurus $R A B$ tersebut, mereka hanya bertandatangan dengan imbalan alakadarnya.

Namun demikian informasi tersebut sulit dikonfirmasi karena Kepala Seksi maupun Sekretaris Desa yang diwawancarai tidak bersedia memberikan jawaban. Akan tetapi jika informasi di atas dikaitkan dengan fakta yang telah diuraikan sebelumnya, yakni Pelaksana Kegiatan tidak terlibat aktif dalam penyusunan RKP Desa, dan penyusunan RKP Desa maupun RAB diarahkan oleh pejabat di Kabupaten, maka dapat diantisipasi pula bahwa Pelaksana Kegiatan akan terbatas peranannya dalam pengajuan pendanaan walaupun tanda tangannya tertera dalam dokumen RAB. mapun surat permintaan pembayaran.

Fenomena proses penganggaran desa yang ditemukan di lokasi penelitian ini menyerupai formalisme proses perencanaan desa sebagaimana yang telah diuraikan dalam bab sebelumnya. Fenomena dimaksud adalah: ada proses penganggaran tetapi tidak sepenuhnya diperankan oleh personil yang secara formal mempunyai posisi untuk itu, ada dokumen anggaran sebagai output dari proses penganggaran, dokumen anggaran dilegalisasi oleh personil yang secara formal mempunyai posisi untuk itu, dan pengajuan pendanaan untuk pelaksanaan kegiatan dilakukan oleh yang bukan pelaksana kegiatan.

Di sisi yang lain ada fenomena pelaksana kegiatan mengetahui bahwa namanya tercantum dalam keputusan kepala desa tentang penetapan PTPKD, pelaksana kegiatan bertandatangan dalam dokumen RAB tetapi bukan pelaksana kegiatan yang melaksanakan pengajuan pendanaan, dan bahwa pelaksana kegiatan memperoleh imbalan untuk tandatangannya dalam dokumen resmi. Fenomena penganggaran desa yang digambarkan di atas menyerupai deskripsi Gordon Tullock tentang rent-seeking atau perburuan rente. Dengan rent-seeking dimaksudkan sebagai perburuan rente di dalam keputusan-keputusan kebijakan publik untuk kemanfaatan pribadi (Hillmana and Ursprung, 2015). Dalam model rent-seeking ini, keputusan-keputusan kebijakan publik diorientasikan untuk perolehan keuntungan pribadi yang dapat merugikan kepentingan publik.

Dari aspek yang lain, fenomena penganggaran desa yang digambarkan di atas menyerupai deskripsi Arief Budiman (1991) tentang birokrat rente. Birokrat rente adalah birokrat yang cenderung memanfaatkan birokrasi bagi keuntungan ekonomi dan politik mereka sendiri. Para birokrat bertindak sebagai rentenir karena menyewakan jabatannya untuk kemanfaatan pribadi. Hal ini sejalan pula dengan deskripsi Fred W. Riggs (2006) 
mengenai birokrat di negara berkembang yang cenderung memandang jabatan birokrasi sebagai alat produksi untuk melakukan akumulasi kekayaan. Tetapi, birokrat rente di lokasi penelitian ini berbeda dengan model birokrat rente dalam gagasan Arief Budiman dan Fred W. Riggs. Dalam model Budiman dan Riggs, birokrat menyewakan jabatan kepada kelompok pengusaha melalui sistem rente, kelompok pengusaha mendapat fasilitas dan perlindungan negara, sedangkan birokrat memperoleh uang. Di lokasi penelitian ini, yang menyewakan jabatan adalah PTPKD, disewakan kepada Kepala Desa. PTPKD memperoleh imbalan uang, Kepala Desa mendapatkan legalisasi dokumen penganggaran.

Penganggaran desa berbasis rent-seeking atau penganggaran desa yang diperankan oleh birokrat rente tidak lain adalah suatu patologi birokrasi atau penyakit birokrasi. Penyakit birokrasi seperti ini bukan hal yang baru tetapi sudah berakar dalam budaya birokrasi Indonesia sejak Orde Baru sebagaimana disinyalir oleh Budiman (1991), bahkan sudah menjadi ciri umum birokrasi negara berkembang sebagaimana disinyalir oleh Riggs (2006), meskipun mempunyai pelaku yang berbeda. Dalam model Budiman maupun Riggs, hubungan rente tercipta antara birokrasi dengan pengusaha. Sebaliknya, dalam penganggaran desa di lokasi penelitian ini, hubungan rente tercipta di antara Kepala Desa dan Perangkat Desa yang diposisikan sebagai PTPKD. Dalam penganggaran desa berbasis rente, PTPKD digunakan namanya sebagai instrumen legal-formal tetapi untuk itu dia memperoleh imbalan.

Penganggaran desa berbasis rente (rent- seeking) diamankan melalui hubungan informal Kepala Desa dengan pejabat di Kabupaten di mana pejabat di Kabupaten membantu membuat atau menyediakan dokumen anggaran yang diperlukan oleh desa dengan imbalan tertentu. Peran pejabat di Kabupaten mensubstitusi peran Tenaga Pendamping Lokal Desa, Tenaga Pendamping Desa, dan Tenaga Ahli. Desa diuntungkan dalam hubungan informal ini, yakni: (l) evaluasi Ranperdes APB Desa dan verifikasi RAB tidak perlu lagi dilakukan secara eksklusif karena yang menyusun adalah pejabat yang sudah berpengalaman di kabupaten, dan (2) perbedaan format penulisan anggaran dengan format yang dianjurkan oleh pemerintah pusat tidak lagi menjadi kendala untuk penetapan Perdes tentang APB Desa dan pencairan dana.

\section{KESIMPULANN}

Kapasitas penganggaran desa di Kabupaten Muna belum optimal, yakni, sistem penganggaran desa belum berfungsi sebagaimana mestinya dalam pengalokasian dan penggunaan input untuk memproduksi output yang bermanfaat bagi pencapaian tujuan-tujuan pembangunan desa. Output penganggaran desa adalah APB Desa dan RAB. Desa-desa di Kabupaten Muna mempunyai mempunyai dokumen APB Desa dan RAB yang ditetapkan dengan Peraturan Desa. Namun, penggunaan input organisasional/manajerial untuk menghasilkan APB Desa dan RAB belum berjalan secara semestinya dan belum merefleksikan good governance, masih menyerupai sistem formalistik, mempunyai karakteristik rent-seeking atau perburuan rente, sedangkan dokumen APB Desa dan RAB yang dihasilkan masih mengandung berbagai kelemahan dalam format struktur maupun kesesuaian teknisnya.

\section{SARAN}

Kapasitas penganggaran desa di Kabupaten Muna membutuhkan optimalisasi agar dapat mendukung pencapaian tujuan pembangunan desa. agar penganggaran desa di Kabupaten Muna sesuai dengan peruntukkannya diperlukan bimbingan dan pemenuhan terhadap input dan out put kapasitas penganggaran yang dibutuhkan. Untuk itu Pemerintah Kabupaten Muna segera melakukan langkah-langkah optimalisasi berdasarkan temuan studi ini. 


\section{DAFTAR PUSTAKA}

Allen, R., and Tommasi, D. (Eds.), 2001. Managing Public Expenditure: A Reference Book For Transition Countries. Paris: OECD.

BPS. 2017. Badan Pusat Statistik. Propinsi Sulawesi Tenggara.

BPS. 2017. Kabupaten Muna dalam Angka. Badan Pusat Statistik Kabupaten Muna.

Boyle, R., \& O'Riordan, J., 2013. "Capacity and Competency Requirements in Local Government." Local Government Research Series, No 5, September 2013.

Budiman, Arief. 1991. Negara dan Pembangunan; Studi tentang Indonesia dan Korea Selatan, Jakarta: Yayasan Padi dan Kapas, Cetakan Pertama.

Denhardt, R.B. and Denhardt, Janet V., 2006. Public Administration: An Action Oriented. Fifth Edition. Belmont: Thomson Higher Education.

Fukuyama, Francis (editor), 2009. Falling Behind: Explaining the Development Gap Between Latin America and the United States. New York, NY: Oxford University Press, Inc.

Hillman, Arye L. and Heinrich W. Ursprung, 2015. "Rent seeking: The Idea, the Reality, and the Ideological Resistance." Presentation on Department of Economics, International Trade and Development Seminar, University of Pittsburgh, October 7, 2015.

Lawlor, John E., 2015. "The Importance of Strategic Planning". Available Online at http://www.practicaldecisions.com/strategic-planning.pdf

Milen, Anneli, 2001. What Do We Know About Capacity Building, An Overview Of Existing Knowledge and Good Practice, world Health Organizetion (Departement of Health Service Provision), Geneva.

Pangkey, Imanuel and Pinatik, Sherly. 2015. Analisis Efektivitas dan Efisiensi Anggaran Belanja pada Dinas Kebudayaan dan Pariwisata Propinsi Sulawesi Utara. Jurnal EMBA. Volume 3 Nomor 4. Desember 2015, hal 33-43.

Riggs, Fred W., 2006. The Prismatic Model: Conceptualizing Transitional Societies. Dalam, Comparative Public Administration: The Essential Readings. Research in Public Policy Analysis and Management, Volume 15. Edited by Eric E. Otenyo and Nancy S. Lind. Oxford: Elsevier Ltd., 17-60.

Saidahmadovich, Mirzoaliev Halim, 2013. Public Expenditure Management and Development Assistance in Tajikistan. Research Report Presented to the Higher Degree Committee of Ritsumeikan Asia Pacific University In Partial Fulfillment of the Requirements for the Degree of Master of Science in International Cooperation Policy Graduate School of Asia Pasific Studies, Japan.

Management Literature For Practitioners in Developing Countries. Overseas Development Institute, London, UK. Online at www.odi.org.uk

Yulianto, Trisno. 2017. Mewujudkan Desa Nol Korupsi. Wacana. Suara Merdeka. Selasa 10 Oktober 2017

Ubels, J., Acquaye-Baddoo,N., and Fowler, A., 2010. Capacity Development in Practice. London: Earthscan Ltd, Dunstan House.

UNDP (United Nations Development Programme), 2011. A Users' Guide to Measuring Local Governance. Norway: UNDP Oslo Governance Centre. Tersedia online pada http://europeandcis.undp.org/cd/show/BlFClF8EF203-1EE9- 
Jounal publiuho is licensed under a Creative Commons Attribution 4.0 International License, which permits unrestricted use, distribution, and reproduction in any medium, provided the original work is properly cited.

UNDP (United Nations Development Programme), 2010. Capacity Development : Measuring Capacity. New York: UNDP. Tersedia online pada https://undg.org/wp-content/uploads/2015/

Waskitojati, Damar, Setyo Handoyo, C. Dwi Wuryaningsih, H. Dwi Prasetyo, Slamet Luwihono, 2016. Policy Note: Model Proses Penganggaran Pembangunan Desa Secara Partisipatif. Salatiga: Penerbit Lembaga Percik.

Undang-Undang Nomor 29 Tahun 1959 tentang Pembentukan Daerah Tingkat II di Sulawesi

Undang-Undang Republik Indonesia Nomor 6 Tahun 2014 tentang Desa.

Undang-Undang Republik Indonesia Nomor 23 Tahun 2014 tentang Pemerintah Daerah.

Peraturan Pemerintah Republik Indonesia Nomor 8 Tahun 2016 Tentang Perubahan Kedua atas Peraturan Pemerintah Republik Indonesia Nomor 60 Tahun 2014 Tentang Dana Desa yang Bersumber dari Anggaran Pendapatan dan Belanja Negara.

Peraturan Pemerintah Nomor 43 Tahun 2014 tentang Peraturan Pelaksanaan Undang-Undang Nomor 6 Tahun 2014 Tentang Desa

Peraturan Pemerintah Pengganti Undang-Undang Nomor 2 Tahun 1964 tentang Pembentukan Kabupaten Muna.

Peraturan Menteri Dalam Negeri Nomor 113 Tahun 2014 tentang Pengelolaan Keuangan Desa.

Peraturan Menteri Dalam Negeri Republik Indonesia Nomor 84 Tahun 2015 Tentang Susunan Organisasi dan

Tata Kerja Pemerintah Desa. 